\title{
Short Communication: \\ Isolation and characterization of the endophytic bacteria, and their potential as maize diseases control
}

\author{
ENDANG MUGIASTUTI», SUPRAYOGI, NUR PRIHATININGSIH, LOEKAS SOESANTO \\ Faculty of Agriculture, Universitas Jenderal Soedirman. Jl. Dr. Suparno, Karangwangkal, Purwokerto Utara, Banyumas 53123, Central Java, Indonesia. \\ Tel./fax.: +62-281-638791, `email: endangmugiastuti@gmail.com.
}

Manuscript received: 13 November 2019. Revision accepted: 6 April 2020.

\begin{abstract}
Mugiastuti E, Suprayogi, Prihatiningsih N, Soesanto L. 2020. Short Communication: Isolation And Characterization Of The Endophytic Bacteria, And Their Potential As Maize Diseases Control. Biodiversitas 21: 1809-1815. Sheath blight and bacterial wilt are diseases that can reduce maize production. Biological control with the endophytic bacteria offers environmentally friendly control for these pathogens. The study aimed to isolate and characterize the endophytic bacteria morphologically and biochemically and to study their potential to control maize diseases, especially sheat blight and bacterial wilt causing pathogens. The study was conducted at the Plant Protection Laboratory, Faculty of Agriculture, Jenderal Soedirman University, from April to August 2019. The study consisted of four stages: isolation and characterization of endophytic bacteria, the antagonism test of the endophytic bacterial to $R$ solani, the antagonism test of the endophytic bacteria to Pantoea sp., and the mechanical test of the endophytic bacteria as biological control agents and plant growth-promoting bacteria. Based on the research, four endophytic bacteria isolates have been successfully isolated, and characterized successfully and found have the potential to be developed as biopesticides to control maize disease, especially $R$. solani and Pantoea sp. Bacillus sp, endophytic from the root (BK.A1; BK.A3; PP.A5) and Bacillus sp. endophytic from the stem (PPD.B2) can suppress the growth of R.solani by more than 50\%, have a strong antagonistic index against Pantoea sp (>4), and can produce protease and lipase enzyme, and phosphate solubilization.
\end{abstract}

Keywords: Bacillus, fluorescent Pseudomonas, Pantoea, Rhizoctonia solani

\section{INTRODUCTION}

Maize is a strategic food commodity in the world. In Indonesia, the government seeks to achieve self-sufficiency in maize through increasing production of sustainable maize. However, these efforts have faced several obstacles; one of them is the presence of plant diseases such as sheath blight caused by Rhizoctonia solani Kuhn, and bacterial wilt caused by Pantoea stewartii. $R$. solani can infect up to the midrib of the cob (Djaenuddin et al. 2017), resulting in up to $100 \%$ decrease in the yield (Muis 2007). Pantoea sp. can attack all stages of the plant causing wilting and leaf blight, and is known as Stewart's wilt (Pataky 2004; Ammar et al. 2014). The pathogens can cause 40-100\% yield loss.

Over the past 3 decades, the concept of sustainable and environmentally friendly agriculture has been carried out by minimizing the use of chemicals, both synthetic fertilizers, and pesticides. In the management of pests and plant diseases, biological control is developed by applying biological agents including endophytic bacteria (Shanti and Vittal 2013). Many endophytic bacteria can pass the endodermic barrier across from the root cortex to the vascular system, and subsequently develop as endophytes in stems, leaves, tubers, and other organs (Compant et al. 2005). The use of endophytic bacteria as biological agents has an advantage compared to rhizosphere bacteria because endophytic bacteria live and survive in the plant tissue during plant development, thus protecting the plants.

Bacillus sp. and fluorescent Pseudomonas are reported to be able to live as endophytes and are widely used as biological control agents for soil-borne and air-borne diseases. The endophytic bacteria could control plant diseases through several mechanisms including competition, hyperparasitism, producing microbial inhibiting compounds (antibiotics, lysis enzymes, other physical or chemical disorders), enhancing plant resistance, and promoting plant growth (Compant et al 2005, Pal and McSpadden-Gardener 2006; Rosenblueth and MartinezRomero 2006).

Based on the mechanisms, the use of endophytic bacteria isolated from maize, both upland and lowland, suggested potentially alternative control for sheath blight ( $R$. solani) and bacterial wilt (Pantoea $\mathrm{sp}$ ). The research aimed to isolate and characterize morphologically and biochemically the endophytic bacteria as well as their potential to control pathogens that cause disease in maize especially $R$. solani and Pantoea sp.

\section{MATERIALS AND METHODS}

This research was conducted at the Laboratory of Plant Protection, Faculty of Agriculture, Jenderal Soedirman 
University, Purwokerto, Central Java, Indonesia, from April to August 2019

\section{Isolation Rhizoctonia solani}

Rhizoctonia solani was isolated from maize with sheath blight symptoms and there was sclerotium as a resistant structure from the pathogenic fungi in Banyumas. R. solani isolation was carried out based on Al-Fadhal et al. 2019. Disease samples were cut $0.5 \times 0,5 \mathrm{~cm}$, then sterilized with $\mathrm{NaOCl}(1 \%)$ for $2 \mathrm{~min}$, and rinsed with sterile water 3 times. Disease samples pieces were then dried using sterile filter papers, and transferred to Petri dishes containing PDA medium to obtain pure $R$. solani isolates.

\section{Isolation Pantoea sp.}

Pantoea sp. was isolated from diseased maize samples taken from the maize growing area in Banyumas Regency according to Coplin et al. (2012); Aini et al. (2013) and Desi et al. (2014). Diseased leaves or stems were washed with running water, then dried with a tissue. Diseased samples were cut $1.5 \times 5 \mathrm{~cm}$, then sterilized with ethanol $70 \%$ and rinsed with sterile water 3 times. Furthermore, the sample was crushed with $5 \mathrm{ml}$ of sterile distilled water using a sterile mortar. The bacterial suspension was streaked on nutrient agar and incubated 3-5 days. Bacterial colonies that exhibit the character of Pantoea sp. were yellow, shiny, slimy, flat or convex, then separated as pure cultures of P. stewartii candidates. The culture was then tested by Gram Reaction (KOH test), Hugh-Leifson test, pigment production in YDC medium, oxidase test, hypersensitivity test, and pathogenicity test on maize.

\section{Isolation and characterization of endophytic bacteria}

Sampling for the isolation of endophytic bacteria was carried out in Banyumas and Purbalingga, Central Java, Indonesia, with purposive stratified random sampling. Samples were taken from two areas of altitude, i.e., lowmoderate lands (0-500 $\mathrm{m}$ above sea level), and highlands (> $500 \mathrm{~m}$ above sea level) (Nuryanto et al., 2014). In each district, 2 locations were selected for the low-medium lands, and 1 location for the highlands. Age of maize plants was 20-30 days after planting, when the number of endophytic microbial populations that can be cultured is in the highest population (Cavaglieri et al. 2009).

The endophytic bacteria were isolated from the roots and stems of healthy maize plants. Roots and stems were washed, sterilized with $70 \%$ ethanol (1 minute), $20 \%$ sodium hypochlorite ( 5 minutes) and Ringer's thiosulfate solution ( 5 minutes). Separately, the roots and stems of 10 $\mathrm{g}$ each were crushed with $90 \mathrm{ml}$ PBS on a sterile mortar. Subsequently, samples were plated on NA and Kings B media (Cavaglieri et al. 2009). To isolate Bacillus sp., the suspension was heated for 10 minutes at $80^{\circ} \mathrm{C}$, before plating on NA. Bacterial isolates were further purified and characterized, such as morphological characteristics, gram properties, catalase tests, and hypersensitivity tests

\section{The antagonism test of endophytic bacterial to Rhizoctonia solani}

The antagonism test of endophytic bacteria on $R$. solani was carried out using the dual culture method. The level of inhibition of antagonist is calculated using the formula (Abidin et al. 2015).

$$
\mathrm{I}=\frac{\mathrm{C}-\mathrm{T}}{\mathrm{C}} \times 100 \%
$$

Where:

I : The level of inhibition of antagonist (\%)

$\mathrm{C}$ : The radius of pathogen colonies opposite antagonist

$\mathrm{T}$ : The radius of the colony of pathogens towards antagonist

The antagonism test of endophytic bacterial to Pantoea sp.

Antagonism testing was carried out using the doublelayer test method (Santiago et al. 2015). Endophytic bacteria to be tested were grown on the nutrient agar medium, incubated at $28 \mathrm{C}$ for 48 hours. In the upsidedown position, $1 \mathrm{ml}$ of chloroform was added to the cup lid and left for 2 hours. Next, add $5 \mathrm{~mL}$ so that $0.6 \%$ water containing $0.5 \mathrm{~mL}$ of Pantoea sp. bacterial suspension. The culture was re-incubated for 24 hours, and there were clear zones around the antagonistic bacterial colony. The antibiotic activity was assessed based on the diameter of the clear zone compared to the diameter of the colony. Characterization of the type of antibiosis can be divided into bactericidal and bacteriostatic types based on Djatmiko et al. (2007).

The mechanism test of endophytic bacteria as controlling agents biological and plant growth-promoting microbial

The testing mechanism of endophytic bacteria was carried out for bacteria that have the potential in testing the antagonism of the fungus $R$. solani and Pantoea sp.

\section{Protease test}

The activity of the ability of antagonistic bacteria to produce extracellular protease enzymes was tested using Skim Milk Agar (SMA) medium. Each bacterium to be tested was grown in a medium SMA and incubated at $28 \mathrm{C}$ for 24-48 hours. The presence of clear zones around the colony shows that positive bacteria produce protease enzymes (Abed et al. 2016). The protease activity index is assessed based on the diameter of the clear zone compared to the diameter of the colony.

$$
\text { Protease index }=\frac{(\text { clear zone diameter-colony diameter })}{\text { Colony diameter }}
$$

\section{Lipase test}

Detection of the ability of bacteria to produce the enzyme lipase was done by growing the antagonistic bacteria on a medium containing $1 \%$ Tween 80 . The presence of lipase enzyme activity was demonstrated by milky white sediment around the bacterial colony, after incubating at $28 \mathrm{C}$ for 4-7 days. The lipolytic index was measured using a formula Djuric et al. (2011). 
Lipolytic index $=\underline{\text { (Milky white diameter-colony diameter })}$ Colony diameter

\section{Phosphatase test}

Detection of the ability of bacteria to produce the enzyme phosphatase was done by growing bacterial isolates on Pikovskaya medium. After incubating for 7 days at $28 \mathrm{C}$, the presence of a clear zone around the bacterial colony shows that the bacteria has the ability to produce the phosphatase enzyme to dissolve phosphates. The solubility index is measured using a formula (Farooq and Bano 2013)

Phosphatase Index $=\underline{\text { (Clear zone diameter-Colony diameter })}$ Colony diameter

\section{RESULTS AND DISCUSSION}

\section{Isolation and characterization of endophytic bacteria}

The results of the exploration, isolation, and characterization of endophytic bacteria obtained 23 isolates of endophytic bacteria, consisted of 9 isolates of the fluorescent Pseudomonas and 14 isolates of Bacillus sp. (Table 1). Fluorescent Pseudomonas colony on King's B was round, with a flat edge, and yellowish-white, to greenish-yellow, gram-negative, rod-shaped, non-spore and fluorescent under ultraviolet light. Singh et al. 2017 reported fluorescent Pseudomonas showed light green, yellowish, creamy, circular, slimy, regular-irregular characteristics. Bacteria have short-long rod forms. The Fluorescent Pseudomonas isolates is gram-negative, which can form catalase, a positive oxidase, needed to grow aerobes. Bacillus sp. was observed with a spherical colony having cell rod-shaped, gram-positive, and endospores within cells (Table 1.). Slepecky and Hempill (2006); Amin et al. (2015) reported Bacillus sp. has the characteristics of a circular colony and punctiform (small round), variations in the entire margin and lobate, white dull, non-slimy, gram-positive, has endospores, flagellum and some are motile.

Based on its distribution, fluorescent Pseudomonas and Bacillus sp. found in all sampling locations, high or lowmedium lands. This shows that fluorescent Pseudomonas and Bacillus sp. spread and can live in various altitudes, both high and low-medium land. Bacon and Hilton 2002; Ganeshan and Kumar 2005 reported P. fluorescens and Bacillus sp., are species of bacteria with a wide range of life and are very adaptive in various environments. Both types of bacteria are also found in the roots or corn stalks. Bacillus sp. and Pseudomonas sp. including a group of endophytic bacteria have a wide range of life and more isolated in maize (Ganeshan and Kumar 2005; Orole and Adejumo 2011; Costa et al. 2013)

\section{Antagonism test between the endophytic bacteria against $R$. solani}

Based on the results of in vitro tests (Table 2), 24 isolates of the endophytic bacteria were able to inhibit the growth of $R$. solani, with varying degrees of inhibition. The endophytic bacteria that have inhibition rates above $50 \%$, i.e fluorescent Pseudomonas BK.A1 (51\%), Bacillus sp. B.K.A1 (55.39\%), Bacillus sp BK.A3 (51.52\%), PP.A5 $(50.66 \%)$, and PPD.B2 $(50.8 \%)$. The effect of the endophytic bacteria in inhibiting the growth of $R$. solani is inversely proportional to the dry weight mycelium. The greater the percentage of inhibition of endophytic bacteria to the growth of $R$. solani, the smaller the dry weight mycelium (Table 2) Endophytic bacteria can inhibit the growth of $R$. solani, which were shown by the inhibitory zone in the area bordering the bacterial streak (Figure 1.A).

The endophytic bacteria have anti-pathogenic properties and can produce antibiotic compounds. The ability of the endophytic bacteria to control plant pathogens occurs through the mechanism of antibiosis, competition, lysis, inducing resistance and producing growth substances. Bacteria capable of producing secondary metabolites that can inhibit growth or damage pathogens (Hastuti et al. 2014). These compounds, including alkaloids, phenols, flavonoids, glycosides, and phytoalexin (Soesanto et al. 2010). Fluorescent Pseudomonas can produce various types of antibiotics including phenazine-1-carboxylic acid, pyocyanin, pyrrolnitrin, and pyoluteorin, 2,4-diacetyl phloroglucinol $(\mathrm{Phl})$. $\mathrm{Phl}$ is a phenolic metabolite with antibacterial and antifungal (Jain and Das 2016). Bacillus species can produce various kinds of volatile compounds and diffusible with strong inhibitory activity against plant pathogens (Lim et al. 2017).

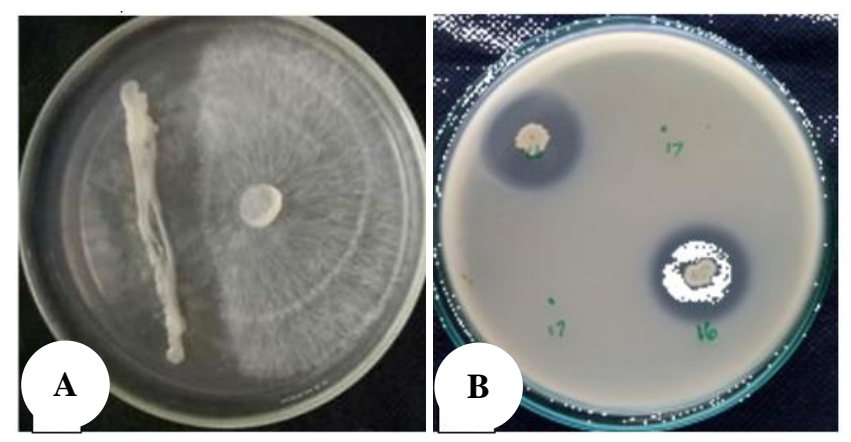

Figure 1. Antagonism test between the endophytic bacteria against $R$. solani (A) and Pantoea sp. (B) 
Table 1. Isolation and characterization of endophytic bacteria.

\begin{tabular}{|c|c|c|c|c|c|c|c|c|c|c|c|}
\hline Land & Sampling location & Sample & $\begin{array}{c}\text { Gram } \\
\text { test }\end{array}$ & $\begin{array}{c}\text { Catalase } \\
\text { test }\end{array}$ & $\begin{array}{c}\text { Oxidase } \\
\text { test }\end{array}$ & $\begin{array}{c}\text { Colony } \\
\text { morpho- } \\
\text { logy }\end{array}$ & Colony pigment & $\begin{array}{c}\text { Fluorescence } \\
\text { on KB } \\
\text { medium } \\
\end{array}$ & Cell morphology & $\begin{array}{l}\text { Endo- } \\
\text { spores }\end{array}$ & Isolate \\
\hline \multirow[t]{7}{*}{ Highland } & \multirow{4}{*}{$\begin{array}{l}\text { Purbalingga, Pratin } \\
7.13 ' 33^{\prime \prime ~ S, ~} 109.17^{\prime 21 " ~ E,} \\
1.190 \mathrm{~m} \text { asl }\end{array}$} & Root & - & + & + & Round & $\begin{array}{l}\text { yellowish- } \\
\text { white }\end{array}$ & + & Medium rod & - & fluorescent Pseudomonas PP.A1 \\
\hline & & Root & + & + & + & Round & White & - & Small rod & + & Bacillus sp. PP.A3 \\
\hline & & Root & + & + & + & Round & White & - & Medium rod & + & Bacillus sp. PP.A5 \\
\hline & & Stem & - & + & + & Round & $\begin{array}{l}\text { yellowish- } \\
\text { white }\end{array}$ & + & Medium rod & - & fluorescent Pseudomonas PP. B4 \\
\hline & \multirow{3}{*}{$\begin{array}{l}\text { Banyumas, Baturaden } \\
7.19^{\prime \prime} 1 " \mathrm{~S}, 109.14^{\prime} 29 " \mathrm{E} \\
520 \mathrm{~m} \text { asl }\end{array}$} & Root & - & + & + & Round & $\begin{array}{l}\text { Greenish- } \\
\text { yellow }\end{array}$ & + & Medium rod & - & fluorescent Pseudomonas BB.A2 \\
\hline & & Root & + & + & + & Round & White & - & Small rod & + & Bacillus sp. BB.A3 \\
\hline & & Stem & + & + & + & Round & White & - & Medium rod & + & Bacillus sp. BB.B4 \\
\hline \multirow[t]{16}{*}{$\begin{array}{l}\text { Medium- } \\
\text { Lowland }\end{array}$} & \multirow{4}{*}{$\begin{array}{l}\text { Banyumas, Sumbang } \\
7.21^{\prime} 54 " \mathrm{~S}, 109.17^{\prime} 33 \text { "E, } \\
200 \mathrm{~m} \text { asl }\end{array}$} & Root & - & + & + & Round & $\begin{array}{l}\text { yellowish- } \\
\text { white }\end{array}$ & + & Medium rod & - & fluorescent Pseudomonas BS.A2 \\
\hline & & Root & + & + & + & Round & White & - & Medium rod & + & Bacillus sp. BS.A1 \\
\hline & & Root & + & + & + & Round & White & - & Small rod & + & Bacillus sp. BS.A3 \\
\hline & & Stem & + & + & + & Round & White & - & Small rod & + & Bacillus sp. BS. B1 \\
\hline & \multirow{3}{*}{$\begin{array}{l}\text { Purbalingga, Bojongsari } \\
7.20^{\prime} 12^{\prime \prime ~ S, ~} 109.20^{\prime} 22^{\prime \prime} \mathrm{E}, \\
190 \mathrm{~m} \text { asl }\end{array}$} & Root & - & + & + & Round & $\begin{array}{l}\text { Greenish- } \\
\text { yellow }\end{array}$ & + & Small rod & - & fluorescent Pseudomonas PB. A 4 \\
\hline & & Stem & + & + & + & Round & White & - & Small rod & + & Bacillus sp. PB. B1 \\
\hline & & Stem & + & + & + & Round & White & - & Medium rod & + & Bacillus sp. BB. B3 \\
\hline & \multirow{5}{*}{$\begin{array}{l}\text { Purbalingga, Padamara } \\
7.22 ' 28^{\prime \prime ~ S, ~} 109.13^{\prime 24 " ~ E,} \\
180 \mathrm{~m} \text { asl }\end{array}$} & Root & - & + & + & Round & $\begin{array}{l}\text { Greenish- } \\
\text { yellow }\end{array}$ & + & Small rod & - & fluorescent Pseudomonas PPD A1 \\
\hline & & Stem & - & + & + & Round & yellowish white & + & Medium rod & - & fluorescent Pseudomonas PPD. B1 \\
\hline & & Stem & - & + & + & Round & $\begin{array}{l}\text { yellowish- } \\
\text { white }\end{array}$ & + & Medium rod & - & fluorescent Pseudomonas PPD. B5 \\
\hline & & Stem & + & + & + & Round & White & - & Small rod & + & Bacillus sp. PPD. B2 \\
\hline & & Stem & + & + & + & Round & White & - & Small rod & + & Bacillus sp. PPD. B4 \\
\hline & \multirow{4}{*}{$\begin{array}{l}\text { Banyumas, Kembaran } \\
7.23^{\prime} 47^{\prime \prime ~ S, ~ 109.17 ' 9 " ~ E, ~} \\
110 \mathrm{~m} \text { asl }\end{array}$} & Root & - & + & + & Round & $\begin{array}{l}\text { yellowish- } \\
\text { white }\end{array}$ & + & Medium rod & - & fluorescent Pseudomonas BK. A1 \\
\hline & & Root & + & + & + & Round & White & - & Medium rod & + & Bacillus sp. BK.A1 \\
\hline & & Root & + & + & + & Round & White & - & Medium rod & + & Bacillus sp. BK.A3 \\
\hline & & Stem & + & + & + & Round & White & - & Medium rod & + & Bacillus sp. BK.B3 \\
\hline
\end{tabular}


Table 2. Inhibition of endophytic bacteria against $R$. solani.

\begin{tabular}{lcc}
\hline Isolate & $\begin{array}{c}\text { Inhibition } \\
\text { rate } \mathbf{\%})\end{array}$ & $\begin{array}{c}\text { Dry weight } \\
\text { mycelium }\end{array}$ \\
\hline Control & 0 & 0.093 \\
Endophytic bacteria from the root & & \\
$\quad$ fluorescent Pseudomonas BB.A2 & 49.00 & 0.038 \\
fluorescent Pseudomonas BS.A 2 & 45.00 & 0.027 \\
fluorescent Pseudomonas BK.A1 & 51.00 & 0.017 \\
fluorescent Pseudomonas PPD.A1 & 10.33 & 0.059 \\
fluorescent Pseudomonas PP.A1 & 38.33 & 0.017 \\
fluorescent Pseudomonas PB.A4 & 18.00 & 0.037 \\
Bacillus sp.BB.A3 & 40.42 & 0.030 \\
Bacillus sp.BS.A1 & 48.73 & 0.016 \\
Bacillus sp. BSA3 & 37.42 & 0.039 \\
Bacillus sp. B.K.A1 & 55.39 & 0.002 \\
Bacillus sp. B.K.A3 & 51.52 & 0.003 \\
Bacillus sp.PP.A3 & 46.65 & 0.019 \\
Bacillus sp.PP.A5 & 50.66 & 0.009 \\
Endophytic bacteria from the stem & & \\
fluorescent Pseudomonas PPD.B1 & 27.00 & 0.020 \\
fluorescent Pseudomonas PPD.B5 & 49.33 & 0.013 \\
fluorescent Pseudomonas PP.B4 & 65.67 & 0.004 \\
Bacillus sp. BB.B4 & 44.44 & 0.026 \\
Bacillus sp. BS.B1 & 49.74 & 0.012 \\
Bacillus sp. BK. B3 & 40.36 & 0.031 \\
Bacillus sp.PPD.B2 & 50.8 & 0.007 \\
Bacillus sp. PPD.B4 & 39.44 & 0.036 \\
Bacillus sp. PB.B1 & 37.29 & 0.047 \\
Bacillus sp. PB.B3 & 44.9 & 0.022 \\
\hline
\end{tabular}

\section{The endophytic bacterial antagonism test against Pantoea sp.}

The results of antagonism between the endophytic bacteria and Pantoea sp. show varied results. The endophytic bacteria that can inhibit bacterial growth were indicated by the presence of clear zones around the endophytic bacterial colonies (Figure1). From the nine isolate fluorescent, Pseudomonas were tested, only three isolates were able to inhibit the growth of the Pantoea sp., i.e fluorescent Pseudomonas (Pf) BS.A2, Pf BK.A1 Pf PPD.B5. While the isolates Pf BB.A2, Pf PPD.A1, Pf PP.A1, Pf PPD.B1, and Pf PP.B4 are not able to inhibit the growth of pathogenic bacteria. Meanwhile, all isolate Bacillus sp. tested (thirteen isolates) were able to inhibit the growth of Pantoea sp. (Table 3).

The presence of clear zones around endophytic bacterial colonies showed the ability of endophytic bacteria to produce antibiotics to inhibit the growth of Pantoea sp. $P$. fluorescens P60 can produce antibiotics that inhibit the growth of pathogens (Soesanto 2011). Pseudomonas fluorescens is reported to produce phenazine-1-carboxylic acid (PCA) and other derivatives, 2,4 diacetyl phloroglucinol (Phl)), pyrrolnitrin (PRN) and or pyoluteorin (Plt) (Heydari and Pessarakli 2010). Nasrun and Burhanudin (2016) mention that $P$. fluorescens produce secondary metabolites, i.e. antimicrobial, cyanide acid and 2,4-diacetyl phloroglucinol phenazine, pyrrolnitrin, pyoluteorin antibiotics.

Table 3. Inhibition of endophytic bacteria against Pantoea sp.

\begin{tabular}{|c|c|c|c|c|}
\hline Isolate & Antagonism & Antagonism index & Antagonism category* & Antagonism activity \\
\hline \multicolumn{5}{|l|}{ Endophytic bacteria from the root } \\
\hline fluorescent Pseudomonas BB.A2 & - & 0 & - & - \\
\hline fluorescent Pseudomonas BS.A 2 & + & 4.91 & Strong & Bacteriostatic \\
\hline fluorescent Pseudomonas BK.A1 & + & 4.42 & Strong & Bacteriostatic \\
\hline fluorescent Pseudomonas PPD.A1 & - & 0 & - & - \\
\hline fluorescent Pseudomonas PP.A1 & - & 0 & - & - \\
\hline fluorescent Pseudomonas PB.A4 & + & 5.29 & Strong & Bactericidal \\
\hline Bacillus sp.BB.A3 & + & 8.17 & Strong & Bacteriostatic \\
\hline Bacillus sp.BS.A1 & + & 4.00 & Strong & Bacteriostatic \\
\hline Bacillus sp. BSA3 & + & 5.07 & Strong & Bactericidal \\
\hline Bacillus sp. B.K.A1 & + & 4.01 & Strong & Bacteriostatic \\
\hline Bacillus sp. B.K.A3 & + & 4.91 & Strong & Bacteriostatic \\
\hline Bacillus sp.PP.A3 & + & 6.63 & Strong & Bactericidal \\
\hline Bacillus sp.PP.A5 & + & 6.56 & Strong & Bactericidal \\
\hline \multicolumn{5}{|l|}{ Endophytic bacteria from the stem } \\
\hline fluorescent Pseudomonas PPD.B1 & - & 0 & - & - \\
\hline fluorescent Pseudomonas PPD.B5 & + & 5.86 & Strong & Bactericidal \\
\hline fluorescent Pseudomonas PP.B4 & - & 0 & - & - \\
\hline Bacillus sp. BB.B4 & + & 7.80 & Strong & Bactericidal \\
\hline Bacillus sp. BS.B1 & + & 6.22 & Strong & Bacteriostatic \\
\hline Bacillus sp. BK. B3 & + & 5.33 & Strong & Bacteriostatic \\
\hline Bacillus sp.PPD.B2 & + & 5.00 & Strong & Bacteriostatic \\
\hline Bacillus sp. PPD.B4 & + & 8.75 & Strong & Bacteriostatic \\
\hline Bacillus sp. PB.B1 & + & 1.67 & Weak & Bacteriostatic \\
\hline Bacillus sp. PB.B3 & + & 5.67 & Strong & Bactericidal \\
\hline
\end{tabular}

Note: $\bullet$ Based on Davis and Stout (1971) 
Table 4. Test results of proteases, lipases and phosphate solubilization

\begin{tabular}{lcccccc}
\hline \multirow{2}{*}{ Isolate } & \multicolumn{2}{c}{ Protease test } & \multicolumn{2}{c}{ Lipase test } & \multicolumn{2}{c}{ Phosphate solubilization } \\
Activity & Index \\
\hline Endophytic bacteria from the root & Activity & Index & Activity & Index & \multicolumn{3}{c}{} \\
$\quad$ Bacillus sp. B.K.A1 & & & & & & \\
$\quad$ Bacillus sp. B.K.A3 & + & 3.75 & + & 3.23 & + & 1.17 \\
$\quad \begin{array}{l}\text { Bacillus } \text { sp. PP.A5 } \\
\text { Endophytic bacteria from the stem }\end{array}$ & + & 3.20 & + & 3.73 & + & 1.27 \\
$\quad$ Bacillus sp.PPD.B2 & + & 5.00 & + & 4.40 & + & \\
\hline
\end{tabular}

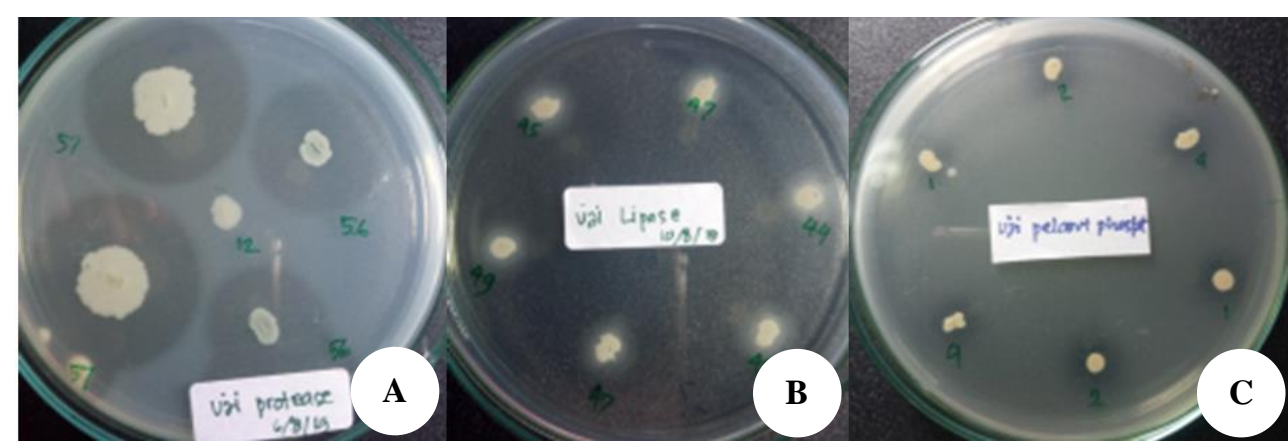

Figure 2. Hydrolysis enzyme activity, (A) protease, (B) lipase and (C) phosphate solubilization

The level of bacteria's ability to inhibit growth can be shown by the large diameter of the clear zone. The results showed that the antagonism index ranged from 1.67-8.17. Based on this index, most endophytic bacteria have a strong antagonism (index of antagonism>4) (Davis and Stout 1971). Furthermore, bacterial isolates that showed antagonistic activity were tested for types of antagonism based on Djatmiko (2007). Based on the type of antagonistic activity, ten isolates the endophytic bacteria were bacteriostatic and nine isolates the endophytic bacteria were bactericidal. Bacteriostatic activity, growth inhibition is temporary, it is shown that regrowth of bacteria after being transferred to a new medium, which is free from the influence of antagonistic bacteria. Bactericidal activity, inhibition is permanent. Bacteria were unable to grow even though they are transferred to new medium.

Test the mechanism of endophytic bacteria as biological control agents and plant growth-promoting microbes

The mechanism test was carried out on endophytic bacteria that have the potential to control the fungus $R$. solani and Pantoea sp., i.e. Bacillus sp. B.K.A1, Bacillus sp. B.K.A3, Bacillus sp. PP.A5, Bacillus sp. PPD.B2. The production of compounds related to biocontrol of pathogens and promotion of plant growth in bacterial isolates was evaluated by measuring the production of antimicrobial compounds and hydrolytic enzymes (amylases, lipases, proteases, and chitinases) and phosphate solubilization. The results of enzyme activity tests are as shown in Table 4. The four isolates Bacillus sp. tested were able to produce protease, lipase and phosphatase enzymes, with varied activity indexes. All isolates of Bacillus sp. those tested had a high index of protease and lipase enzymes (> 3) (Table 4, Figure 2). Protease and lipase enzymes, related to the ability of the endophytic bacteria as biological control agents. Based on the protease and lipase indexes, Bacillus sp. PP.A5 can produce the highest proteases and lipase enzymes compared to other isolates. The isolates that have high protein and fat hydrolysis enzymes have the potential as biological control agents because proteins and fats are constituents of pathogen cells (Mota et al 2016). Besides, the protease enzyme is thought to degrade antibiotics produced by fungal or bacterial pathogens. According to Anderson et al. (2014), the extracellular protease enzyme produced by $P$. fluorescens can inactivate antibiotic compounds produced by Pantoea agglomerans.

Bacillus sp. PPD.B2 has the highest phosphate solubility index. The phosphate solubilization is related to the ability of endophytic bacteria as a plant growth promoter, providing phosphates for plants. Microbes with high phosphate solubility activity are capable of producing and releasing metabolites such as organic acids that chelate cations that are bound to phosphate (especially calcium) and converting them into soluble forms. Solubilization of different forms of phosphate by microbes associated with plants, and increasing its availability for plants, will increase growth and production of the plant (Djuric et al., 2011).

In conclusion, based on research carried out, it has been successfully isolated, morphologically and biochemically characterized four the endophytic bacteria that have the potential to be developed as biopesticides to control maize disease, especially $R$. solani and Pantoea sp. They can suppress the growth of R.solani by more than $50 \%$, have a 
strong antagonistic index against Pantoea sp (>4), and can produce protease and lipase enzyme, and phosphate solubilization.

\section{ACKNOWLEDGEMENTS}

This research was a part of the main study funded by Doctoral Dissertation Grant from the Indonesian Ministry of Research, Technology and Higher Education; for that, I deeply thank for the financial support.

\section{REFERENCES}

Abed HN, Rouag N, Mouatassem D, Rouabhi A. 2016. Screening for Pseudomonas and Bacillus antagonistic rhizobacteria strains for the biocontrol of fusarium wilt of chickpea. Eurasian J Soil Sci 5 (3): 182-191

Abidin Z, Aini LQ, Abadi AL. 2015. Effect of Bacillus sp. and Pseudomonas sp. On the growth of the pathogenic fungus Sclerotium rolfsii Sacc. causes of seedling diseases in soybean plants. Jurnal HPT 3 (1): 1-10.

Aini LQ, Suryani L, Sugiharto AN, Abadi A. 2013. Identification of bacterial wilt and leaf blight disease on maize (Zea Mays) found in Kediri, Indonesia. Agrivita 35 (1): 1-7.

Al-Fadhal FA, AL-Abedy AN, Alkhafijel DA. 2019. Isolation and molecular identification of Rhizoctonia solani and Fusarium solani isolated from cucumber (Cucumis sativus L.) and their control feasibility by Pseudomonas fluorescens and Bacillus subtilis. Egypt J Biol Pest Control 29 (47): 1-11. DOI: 10.1186/s41938-019-0145-5

Amin M, Rakhisi Z, Ahmady AZ. 2015. Isolation and Identification of Bacillus Species From Soil and Evaluation of Their Antibacterial Properties. Avicenna J Clin Microb Infec 2 (1): e23233. DOI: 10.17795/ajcmi-23233.

Ammar, E, Correa VR, Hogenhout SA, Redinbaugh MG. 2014 Immunofluorescence localization and ultrastructure of Stewart's wilt disease bacterium Pantoea stewartii in maize leaves and in its flea beetle vector Chaetocnema pulicaria (Coleoptera: Chrysomelidae). J Microsc Ultrastructure 2: 28-33.

Anderson LM, Stockwell VO, Loper JE. 2004. An extracellular protease of Pseudomonas fluorescens inactivates antibiotics of Pantoea agglomerans. Phytopathology 94: 1228-1234

Bacon CW, Hinton DM. 2002. Endophytic and Biological Control Potential Of Bacillus Mojavensis And Related Species. Biol Control 23: 274-284.

Cavaglieri L, Orlando J, Etcheverry M. 2009. Rhizosphere microbial community structure at different maize plant growth stages and root locations. Microbiol Res 164 (4): 391-399.

Compant SB, Duffy, Nowak J. Clement C, Barka EA. 2005. Use of plant growth-promoting bacteria for biocontrol of plant diseases: principles, mechanism of action, and future prospects. Appl Environ Microbiol 71 (9): 4951-4959.

Coplin DL, Redinbaugh MG. 2012. The bacterium Pantoea stewartii uses two different Type III secretion systems to colonize its plant host and insect vector. Appl Environ Microbiol 78 (17): 6327-6336.

Costa FG, Zucchi TD, de Melo IS. 2013. Biological control of phytopathogenic fungi by endophytic actinomycetes isolated from maize (Zea mays L.). Braz. Arch Biol Technol 56 (6): 948-955.

Davis WW, Stout TR. 1971. Disc plate methods of microbiological antibiotic assay. Appl Microbiol 22 (4): 659-665.

Desi Y, Habazar T, Agustian, Khairul U, Syamsuwirman, Novia P. 2014. Morphological dan physiological characterization of Pantoed stewartii subsp. stewartii from maize. Jurnal Fotopatologi Indonesia 10 ( 2): 45-52. DOI: 10.14692/jfi.10.2.45. [Indonesian]

Djaenuddin N, Nonci N, Muis A. 2017. Effectiveness of the formula Bacillus subtilis TM4 for disease control in maize plants. Jurnal Fitopatologi Indonesia 13 (4): 113-118. [Indonesian]

Djatmiko HA, Arwiyanto T, Hadisutrisno B, Sunarminto BH. 2007. Potential of three bacterial genera from three plant rhizosphere as biological agents controlling Lincat disease. Jurnal ilmu-ilmu Pertanian 9 (1): 40-47. [Indonesian]
Djuric S, Pavic A, Jarak M, Pavlovic S, Starovic M, Pivic R, Josic D. 2011. Selection of indigenous fluorescent pseudomonad isolates from maize rhizospheric soil in Vojvodina as possible PGPR. Romanian Biotechnolo Lett 16 (5): 6580-6590. DOI: 10.1094/PHI-I-2004-011301.

Farooq U, Bano A. 2013. Screening of indigenous bacteria from rhizosphere of maize (Zea mays L.) for their plant growth promotion ability and antagonism against fungal and bacterial pathogens. J Anim Plant Sci 23 (6): 1642-1652.

Ganeshan G, Kumar AM. 2005. Pseudomonas fluorescens, a potential bacterial antagonist to control plant diseases. J Plant Interact 1 (3): 123_134.

Hastuti RD, Saraswati R, Sari AP. 2014. The effectiveness of the endophytic microbes in promoting plant growth and controlling leaf blight disease in the lowland rice. Jurnal Tanah dan Iklim 38 (2): 109118. [indonesian]

Heydari A, Pessarakhi M. 2010. A review on biological control of fungal plant pathogens using microbial antagonists. J Biol Sci 10 (4): 273290

Jain A, Das S. 2016. Insight into the interaction between plants and associated fluorescent Pseudomonas spp. Intl J Agron. DOI: $10.1155 / 2016 / 4269010$

Lim SM, Yoon M, Choi GJ, Choi YH, Jang KS, Shin TS, Park HW, Yu NH, Kim YH, Kim J. 2017. Diffusible and volatile antifungal compounds produced by an antagonistic Bacillus velezensis G341 against various phytopathogenic fungi. Plant Pathol J 33 (5): 488-498. DOI: 10.5423/PPJ.OA.04.2017.0073

Motaa MS, Gomes CB, Júniora ITS, Moura AB. 2017. Bacterial selection for biological control of plant disease: criterion determination and validation. Braz J Microbiol 48: 62-70

Muis A. 2007. Management of sheath blight disease (Rhizoctonia solani Kuhn.) in maize. Jurnal Litbang Pertanian 26 (3): 100-103 Desi 2014 [indonesian]

Nasrun, Burhanudin. 2016. Evaluation of the efficacy of the formula Pseudomonas fluorescens for controlling bacterial wilt (Ralstonia solanacearum) patchouli. Buletin Penelitian Tanaman Rempah dan Obat, 27 (1): 67-76. [Indonesian]

Nuryanto B, Priyatmojo A, Hadisutrisno B. 2014. Pengaruh tinggi tempat dan tipe tanaman padi terhadap keparahan penyakit hawar pelepah. Penelitian Pertanian Tanaman Pangan 33 (1): 1-8. [Indonesian]

Orole OO, Adejumo TO. 2011. Bacterial and fungal endophytes associated with grains and roots of maize. J Ecol Nat Environ 3 (9): 298-303.

Pal KK, McSpadden-Gardener B. 2006. Biological Control of Plant Pathogens. The Plant Health Instructor. DOI: 10.1094/PHI-A-20061117-02

Pataky JK. 2004. Stewart's wilt of corn. The Plant Health Instructor. DOI: 10.1094/PHI-I-2004-0113-01.

Rosenblueth M, Martinez-Romero E. 2006. Bacterial endophytes and their interaction with hosts (Review). Mol Plant Microbe Interact 19 (8): 827-837.

Santiago TR, Grabowski C, Rossato M, Romeiroa RS, Mizubuti ESG. 2015. Biological control of eucalyptus bacterial wilt with $\begin{array}{llll}\text { rhizobacteria. Biol Contr 80: 14-22. DOI: } & \end{array}$ 10.1016/j.biocontrol.2014.09.007.

Shanti AT, Vittal RR. 2013. Biocontrol potencials of plant growth promoting rhizobacteria against Fusarium wilt disease of cucurbit. J Plant Pathol 2 (3): 155-161.

Singh S, Dutta U, Bhat AK, Gupta S, Gupta V, Jamwal S. 2017.Morpho cultural and biochemical identification of Pseudomonas sp. isolated from the rhizosphere of different vegetable crops and study its efficacy on Solanum melongena (Brinjal). J Pharmacogn Phytochem 6 (2): 22-28

Slepecky R.A., Hemphill H.E. 2006. The Genus Bacillus-Nonmedical. In: Dworkin M, Falkow S, Rosenberg E, Schleifer KH, Stackebrandt E. (eds.). The Prokaryotes. Springer, New York.

Soesanto L, Mugiastuti E, Rahayuniati RF. 2010. Study of the antagonistic mechanism of Pseudomonas fluorescens P60 against Fusarium oxysporum f.sp. Lycopersici in tomatoes in vivo. Jurnal HPT Tropika 10 (2): 108-115

Soesanto L, Mugiastuti E, Rahayuniati RF. 2011. Utilization of some animal broths as a liquid formula for Pseudomonas fluorescens P60 to control Sclerotium rolfsii in cucumber plants. Jurnal Perlindungan Tanaman Indonesia 17 (1): 7-17. 